\title{
Issues in Accrual Accounting and Budgeting by Government
}

\begin{abstract}
Allan Barton
$\mathrm{T}$

The adoption of accrual accounting and budgeting systems has been central to the program of Commonwealth Public Sector reforms over the past 20 years. The reforms are explained in publications such as Department of Finance (DOF, 1994a,b), National Commission of Audit (1996); Guthrie and Parker (1998); and Wanna, Kelly and Forster (2000). They were heralded with much praise and promise for improvements in the efficiency of resource management and effectiveness in policy delivery, and in enhanced transparency of information and accountability to Parliament and the public. However, while major improvements have been made in these matters, significant concerns remain about the new systems and they have created many problems.

The fundamental features of the new financial measurement systems and the problems they have created are reviewed in the paper. The problems arise from the scrapping of the former cash accounting and budgeting system (CABS) upon the introduction of accrual accounting, and secondly, from the simultaneous introduction of two distinctly different accrual accounting and budgeting systems (AABS) - the Australian Accounting Standards (AAS) system and the Government Finance Statistics (GFS) system. It is contended that:
\end{abstract}

- a CAB system should be reintroduced because it provided necessary information for the management of government fiscal policies and cash;

- $\quad$ only one AAB system should be used;

- the GFS system, as upgraded, should be the one adopted as it provides the information required by governments, and the AAS system should be discontinued as it has limited relevance to the environment of governments;

- the CAB system should be designed as an integral component of the AAB system.

This paper begins by briefly examining the role of accounting as a financial management information and reporting system in government, and the nature and roles of government so as to establish its financial information needs. I then examine the nature of each of the three accounting systems and the types of information provided by each, followed by my conclusions and recommendations. The paper is confined to the activities of the general government sector of the Commonwealth Government and to the information published in regular

Allan Barton is Emeritus Professor in the School of Business and Information Management, The Australian National University. 
government financial statements. While it does not refer to state and territory governments, the same principles apply to them.

\section{Accounting as a Financial Management Information and Reporting System}

The purpose of an accounting system is to provide useful financial information. In the public sector context, accounting should be regarded as a financial management information and reporting system (FMIRS) for use of management, parliament and the public as the key stakeholders. The Australian Accounting Standards Board's Statement of Accounting Concepts (SAC) states that it should report information useful for decision making in the use of resources, performance measurement and accountability purposes (SAC2, 1990:paras 43-45).

Information can be useful only if it satisfies certain criteria and is appropriate for the functions and roles of the accounting entity. These criteria comprise relevance, reliability, comparability and understandability, and are explained in SAC3 (1990:para 5). Relevant information must relate to the purposes for which it is to be used, that is, the decisions made, measurement and assessment of financial position and performance, and the fulfilment of accountability obligations. To be relevant and timely, it must be tailored to suit the operating environment of the entity and the concepts being measured. Reliable information requires that it represents faithfully the transactions, concepts and results of operations that it purports to represent and do so without bias or undue error. Comparable information requires the use of consistent accounting concepts and practices so that like information can be validly compared within and between statements, over time and between entities. Understandability means that users are readily able to comprehend what the information purports to mean. This requires that the presentation of information must not be obfuscated by irrelevant information, non-disclosure of key items, and inappropriate terminology, classification of items or accounting practices. The first three criteria for useful information are interrelated and they all impact on understandability. These criteria comprise the necessary conditions for the financial statements to present a 'true and fair' view of the financial results of an entity's activities.

FMIRS can take a variety of forms according to the information required from them. They may encompass cash transactions only (cash based accounting) or all cash and accrual transactions (partial accrual accounting); they may include other accounting events, that is, non-transactions which affect income and wealth such as asset consumption charges (that is, full accrual accounting); they may adopt initial transaction prices of assets and liabilities (historic cost accounting) or their current market values as the basis of income and wealth measurement (current value accounting); and they may use the dollar measuring rod as a unit of exchange or as a unit of general purchasing power (real value systems). Finally, the systems can relate to the past and record actual transactions and events, or to expected future transactions and events. 
The only financial report which can be prepared in the cash based accounting system is the Cash Flow Statement, and the only asset reported is the cash balance. Two financial statements can be prepared under partial accrual accounting - a cash flow statement and a summary of external transactions (both for cash and credit). Full accrual accounting systems are required to measure income and financial position in addition to the cash flow and all external transactions reports. These involve the measurements of all items of revenue and expense, and all assets and liabilities, and a matching of expenses against revenue to determine profit. As well, detailed management reports on segments of operations (products, departments etc) can be prepared in the system.

The nature and characteristics of these systems are explained in Barton (1984:Chaps 24-28). The information produced in each system differs, and the choice between them depends upon the type of information required. No one system can provide all the financial information possibly required.

\section{Nature and Role of Government}

The nature and role of government determine what information is required from the FMIRS. They establish the environment in which the accounting system is to operate and the purposes for which the information is to be used. In turn, these matters determine what and how the information is to be measured and reported.

The nature and role of government vary from nation to nation and over time. They can raise very important political issues which ultimately must be resolved by the citizens of a democratic nation. Governments typically undertake the following roles (see, for example, Stiglitz, 1999):

- $\quad$ provision of public goods and services to citizens

- provision of social welfare goods and services to citizens

- macro-economic management of the economy

- pursuit of intergenerational equity

- conservation of the nation's heritage and natural environment

- management of government resources and liabilities.

The above activities of government determine its financial management information needs. The first five roles are the concern of government fiscal policies. They all involve the raising and expenditure of cash, and significant externalities. Accordingly, the Commonwealth Government (Budget Papers, 2001:8.2) sees the role of its General Government Sector (GGS) as the provision of ' ... public services that are mainly non-market in nature, and for the collective consumption of the community, or involve the transfer or redistribution of income. The services are largely funded through taxation and other compulsory levies.' The resource and liability management role is primarily a departmental management responsibility. Fiscal policies are formulated for the nation and must be approved by parliament prior to their implementation. Resource and liability management is a micro-economic responsibility vested in departmental managers 
implementing government policies as approved by parliament. Their good management is covered by statute, for example, Financial Management and Accountability Act (FMA) 1997, Audit Act 1997 and the Public Service Act 1999.

\section{Major Issues and their Solution}

\section{Cessation of Cash Accounting and Budgeting Systems}

Cash Accounting and Budgeting Systems have been used by all Australian Governments since birth. The Department of Finance (1994:9) succinctly summarises the role of cash accounting in the Westminster system as:

Historically, governments have operated on an annual cash basis because this is fundamental to the democratic constitutional safeguards which have been evolving since the days of King Charles I of England. The basic safeguard is that no monies shall be collected or spent except in ways and amounts approved by Parliament through budget appropriations.

These requirements are included in the Australian Constitution 1901 (Section 83) and in the FMA Act 1997. All policies involving cash transactions, both receipts and payments, must first be approved by Parliament prior to implementation. They must also pass through the Consolidated Revenue Fund (Section 81). Information on budget compliance must also be submitted to Parliament, and be audited (Audit Act 1997) to certify that Parliament's wishes have been adhered to. Evidence of budget compliance is an integral part of the accountability process.

Notwithstanding the above requirements, as well as its essential role in fiscal policy determination and cash management, CABS was terminated without public warning upon the introduction of the AAS system of accrual accounting and budgeting in the May 1999 budget. Yet most of the literature supporting the adoption of accrual accounting by government stressed that CABS should be retained as part of the more comprehensive accrual accounting system. This included official reports (DOF, 1994a,b), reports of AARF which formulates draft accounting standards (Sutcliffe, Michallef and Parker, 1991; Micallef, Sutcliffe and Doughty, 1994), and articles by individual authors (Guthrie and Parker, 1998). For example, the National Commission of Audit (NCA, 1996:223) states:

Thus, the short to medium term cash impact of the budget will continue to be important for macro-economic management purposes ... accrual budgets would continue to provide this cash information.

As the preceding explanation of FMIRS indicates, there is no technical reason why cash flow reports prepared directly from cash transactions cannot be prepared daily in an accrual accounting system. Many corporations do so as the information is needed for efficient cash management. In government, it is needed 
for this purpose but as well for fiscal policy management and accountability purposes.

Cash is central to all government fiscal policies because it funds the resources required to provide all the goods and services to the community. Cash budgets provide parliament with information on the new resources required for allocation to departments and programs, and thence to citizens in the form of the types of goods and services discussed above; and secondly, on how they are to be funded through taxation and other measures. Provision of new resources involves government policy decisions and parliamentary approval.

Furthermore, cash is central to macro-economic management of the economy. All transactions affect the level of economic activity - production, sales and employment. The cash budget also impacts on financial markets and interest rates. Deficits must be funded through government borrowing, while surpluses add to the savings of the nation and are available to fund investment expenditure. Long term cash budgets extending over the economic cycle are also needed to determine whether current policies are compatible with the objective of intergenerational equity. A long term cash deficit indicates that, on current expectations, taxation receipts are inadequate to fund the budgeted provision of services.

CABS is also necessary for efficient cash management by government to ensure adequate liquidity throughout the year and to minimise borrowing costs. With annual cash operating budget inflows and outflows each exceeding $\$ 250,000 \mathrm{~m}$, the flow of cash through the Government is enormous by business standards. In addition there are significant capital transactions and loan repayments. Because there can be substantial fluctuations in daily cash flows, the Government must ensure it has sufficient cash on hand each day to meet its expenditures, and if a deficit is expected, it must arrange to borrow the money in advance through the sale of Treasury notes. Conversely it can invest temporary cash surpluses to redeem some Treasury notes. Rolling cash budgets must be prepared each day for efficient cash management.

Hence for fiscal policy purposes, efficient cash management, and budget legal compliance and accountability purposes, CABS is necessary, and the information must be available on a timely basis. This can be done where the information is compiled directly from cash transactions undertaken each day. Unfortunately the only cash flow statements (CFS) currently prepared are annual ones and these are of no use for cash management or intra-year macro-economic management purposes. Furthermore, the statements are prepared from each set of end-of-year accrual financial statements (GFS and AAS) by eliminating all the non-cash transactions and events from them. This is an inefficient process which takes about 3 months to accomplish. But by then, the information is too out of date for management use. As well, the information may not be fully reliable as would be expected from a cash flow statement purportedly reporting factual information on cash transactions. The cash balances from all activities calculated in each of the systems differ by not insignificant amounts. For example, for the 2005-06 budget, the GFS CFS reports an operating surplus of $\$ 12,198 \mathrm{~m}$, while the 
AAS statement reports one of $\$ 15,583 m$ (Budget Paper No. 1, Statement 9:6, and Statement 10:4), that is, a difference of $\$ 3,385 \mathrm{~m}$.

Hence, a major reform to the present FMIR systems must be the reintroduction of CABS to enable the regular preparation of cash flow statements directly from cash transactions. CABS can be readily incorporated into the accrual GFS system as a distinct reporting segment as both systems are based on recording transaction resource flows. Moreover, in excess of 80 per cent of the Government's transactions involve immediate cash flows. Parliament requires cash budgets reporting to fulfil its legal responsibilities for approving all budget proposals; and they are required for fiscal policy determination, accountability for budget compliance, the Appropriation Bills and for cash management. The presentation of cash budgets should distinguish between current operating expenditures and capital expenditures on non-financial assets because it is an important distinction for interpretation of the budget's effects on the economy and intergenerational equity, and for comparison with accrual budgets.

\section{Adoption of two accrual accounting and budgeting systems}

The case for adoption of accrual accounting and budgeting systems (AABS) is an overwhelming one. Without AABS, the government has no systematic records of its vast holdings of non-cash assets and portfolio of liabilities. As at 30 June, 2004, the General Government Sector of the Commonwealth Government had financial assets of $\$ 71,157 \mathrm{~m}$ and non-financial assets of $\$ 72,778 \mathrm{~m}$ (Consolidated Financial Statements:82, based on AAS). Conversely, it had liabilities for borrowings, staff superannuation and other obligations of $\$ 186,621 \mathrm{~m}$. This left a deficit in its net worth of $\$ 77,949 \mathrm{~m}$, offset by reserves of $\$ 35,263 \mathrm{~m}$ (mainly asset revaluation), to yield a net equity of negative $\$ 42,686 \mathrm{~m}$.

There can be no effective management of such a vast portfolio of assets and liabilities without appropriate accounting records of them. Furthermore under CABS, management attention was concentrated on fiscal policy issues, cash budget compliance and cash management, and a refocusing of management attention to encompass all the non-financial assets and liabilities of the Government required 'a cultural change' (JCPA, 1995a). As a result, many assets were surplus to requirements, under-utilised or poorly maintained (ANAO, 1995-96). Likewise, burgeoning liabilities from budget deficits and unfunded superannuation commitments were largely ignored. As well, accrual accounting is needed for cost control of departmental operations and of programs for delivery of services to the public. This information is necessary for determining priorities in expenditure programs, and for facilitating better management of government resources and hence efficiency of operations. In brief, accrual accounting is required for the final resource management role of government.

Given the undeniable potential for accrual accounting to yield substantial efficiency benefits, the major issue concerning its adoption is not whether it should be adopted, but which system of AABS should be adopted. The Government in fact adopted two very different systems of accrual accounting - the 
Government Finance Statistics (GFS) standard of the IMF and the Australian Accounting Standards (AAS) system formulated by the Australian Accounting Standards Board (AASB). AAS are the professional accounting standards developed for and used by business. Almost the whole package of AAS and the Statements of Accounting Concepts (SACs) apply to the public sector. However the ones of major relevance comprise AAS29, Financial Reporting by Government Departments (1996), AAS31, Financial Reporting by Government (1996) and the SACs (1990). Table 1 below illustrates the figures produced under each system for the 2005-2006 Commonwealth Budget.

Table 1: Comparison of AAS and GFS Budgets 2005-2006

\begin{tabular}{|c|c|c|c|}
\hline & AAS31 & GFS & Difference \\
\hline \multicolumn{4}{|l|}{ Operating Statements } \\
\hline \multirow{5}{*}{$\begin{array}{l}\text { Total Revenues } \\
\text { Total Expenses } \\
\text { Net Operating Results } \\
\text { Balance Sheets }\end{array}$} & \multicolumn{3}{|c|}{ \$million } \\
\hline & 217,869 & 252,511 & 34,642 \\
\hline & 209,074 & 243,521 & 34,447 \\
\hline & $\$ 8,794$ & $\$ 8,990$ & $\$ 196$ \\
\hline & \multicolumn{3}{|c|}{ Balance Sheets } \\
\hline Financial Assets & 87,554 & 130,507 & 42,953 \\
\hline \multicolumn{4}{|l|}{ Non-Financial Assets } \\
\hline \multicolumn{4}{|l|}{ Total Assets } \\
\hline \multicolumn{4}{|l|}{ Liabilities } \\
\hline \multicolumn{4}{|l|}{ Net Worth } \\
\hline \multicolumn{4}{|l|}{ Cash Flow Statements } \\
\hline Cash operating surplus & 15,583 & 12,198 & $-3,385$ \\
\hline Net purchase of assets & 14,802 & 11,547 & $-3,255$ \\
\hline \multirow{2}{*}{$\begin{array}{l}\text { Net debt repayment } \\
\text { Net reduction in cash }\end{array}$} & 1,420 & 1,291 & -129 \\
\hline & $\$ 639$ & $\$ 639$ & - \\
\hline
\end{tabular}

Source: Budget Paper No. 1, 2005-06, Statement 9:4-6; Statement 10:2-4.

As is evident, the figures produced by each system are substantially different (except, fortunately, for the closing cash balance change). This is a most unsatisfactory situation. It confuses Parliament, permits of 'cherry picking' by ministers and parliamentarians selecting the figures which better suit their arguments, and leads to questions as to what is 'the truth' - which set of budget figures should Parliament approve; how much tax revenue does the Government expect to collect; what are the total costs of running Government activities; what is the real budget balance; what are the values of the Government's assets and liabilities; and so on? No company would be allowed to publish two sets of financial statements, yet the Government does so. Furthermore, the cash appropriation bills which Parliament must approve have little obvious relationship 
with either set of accrual budgets. This is no way to run the complex business of government. Parliament is dissatisfied with the situation and the JCPAA(2002) held an inquiry into the problems. However the Committee remained confused and was unable to resolve it. The Government acknowledges the problem and a senior Treasury committee (the Heads of Treasury Accounting and Reporting Advisory Committee - HOTARAC) was charged with developing a set of changes for the consideration of the AASB to harmonise them into a single accounting system suitable for the needs of government at both the macro and micro levels (Challen and Jeffery, 2003).

The AAB system based on the GFS standards was introduced in 1993 for the General Government Sector (GGS) for both budget and outcome statements. However, its use was confined to the macro level for fiscal policy management and the statements were not published; it was not applied at the departmental level for resource management purposes. It was used by Treasury in conjunction with CABS until 1999, when CABS was discontinued upon the introduction of the AAS accrual budgets. At the same time, the direct recording of cash transactions was abolished with the scrapping of the cash transactions recording system. Also in 1999, the GFS budgets were published for the first time, and in 2000, the outcome statements for GGS (as appendices to the consolidated whole-ofgovernment reports).

Accrual accounting based on AAS was introduced progressively by departments from about 1990, and the first departmental outcome statements were produced in 1993. The first set of draft consolidated financial statements for the whole-of-government were completed in 1995 . AAS budget statements were introduced for both departments and the GGS in 1999, and CABS was discontinued. Thus since 1999, both AABS budget and outcome statements have been published, though the budgets are for the GGS only and the audited outcome statements for the whole-of-government only.

The AAS budgets are the ones formally presented to Parliament for approval and the consolidated outcome statements for the whole-of-government are audited by the Auditor General. These are requirements of the Charter of Budget Honesty Act, 1998. But this should not be interpreted to imply that the AAS statements are of superior quality to the GFS statements. There are some major anomalies and limitations in the AAS standards when applied to the public sector, and some of these are examined below (see also Barton, 2003). A major anomaly of relevance at this stage of the examination concerns the accounting and reporting entity. While each department is an entity under AAS29, only the whole-of-government is an accounting and reporting entity under AAS31. Hence the GGS is not regarded as an entity under AAS, notwithstanding that the AAS budget is confined to the GGS and requires parliamentary approval. As a result, there are no outcome financial statements for the GGS subject to audit, and the budget statements cannot be readily matched against the outcome statements for users to analyse the differences. Yet budget/outcome comparisons are required for good management and accountability purposes. This confusing subject is examined in Challen and 
Jeffrey (2005). Both sets of AAB systems are explained and examined below to isolate the causes of the differences between them.

\section{Government Finance Statistics - Accrual Accounting and Budgeting System}

The GFS system (IMF 2001) was developed specifically for the public sector to accommodate the special nature and role of the GGS and for assessing its economic impact on the nation, that is, for macro fiscal policy purposes. It was not intended to cover the micro departmental resource management function of government.

The system is based on IMF economic measurement standards used for the measurement of Gross Domestic Product of nations and its components, and is integrated with the UN System of National Accounts. The system enables relevant and reliable measurements of GDP to be made which are internationally comparable. It is an economic measurement system based on economic concepts throughout and uses a rigorous, analytical approach. It is based on double entry recording, a sharp distinction between stocks and flows of resources, and current market prices of all assets and liabilities (primarily buying prices for non-financial assets and realizable prices for financial assets and liabilities).

A sharp distinction is made between stocks and flows of resources in the system because of their differing economic effects. Resource flows directly affect production, sales and employment and enter into the GDP; as well they affect the stocks of resources (that is, assets, liabilities and net assets or wealth). Changes in resources can also arise from some non-transaction events such as changes in market prices, discovery of new mineral deposits and the growth of forests.

Two types of resource flows are distinguished: transactions and other economic flows. Transactions represent resource flows that come about as a result of mutually agreed interactions between the government and external parties. Under accrual accounting, these flows are recognised as and when they occur. Transactions are classified into exchange transactions which involve the purchase and sale of items; and taxes and transfers (such as social welfare payments) which provide goods, services or cash to or from the government without receiving something in return. Internal asset consumption, for example, depreciation of non-financial assets and inventory consumption, is recognised along with transaction resource flows as it reduces resources even though it does not involve a market transaction. These resource flows are summarised in a Statement of Government Operations, and they all impact on the stock of assets and liabilities shown in the balance sheet.

Other economic flows represent changes to stocks that do not result from transactions or from internal asset consumption. They arise from price movements and abnormal events. They often arise passively without any active decision making being involved. Valuation changes in stocks of resources arise from price changes in individual assets and liabilities. They are holding gains and losses which do not alter the physical stock of resources. All assets and liabilities 
are revalued at current market prices prevailing at the end of each year, and holding gains and losses are then recognised. Abnormal items include damage caused by natural disasters (earthquakes, bushfires, floods, etc), discovery of new mineral resources, and growth of forests etc. However they are excluded from normal operating resource flows because (for most items) they are irregular and largely unpredictable, and are therefore not amendable to normal macro-economic management policies. The valuation changes and abnormal items are summarised in a Statement of Other Economic Flows. They are recorded directly as balance sheet changes and do not enter into the Statement of Government Operations. Finally, all stocks of resources and liabilities at the end of the year are summarised (at current market values) in the balance sheet.

The Statement of Government Operations shows that (Revenue less Expenses) equals Net Operating Balance $=($ Nonfinancial asset transactions and net lending/borrowing) = (Financial asset transactions - liability transactions). The net operating balance flows through to transactions in assets and liabilities, and ultimately the balance sheet. The statement provides the government with some important economic magnitudes - net operating balance; gross and net capital formation by government; and net lending/borrowing which in turn is represented by the increase in financial assets/liabilities. The net operating balance indicates the ongoing sustainability of government operations. Gross and net capital formation show government investment expenditure on additional physical assets which are important generators of economic growth, and on provision of community facilities. Net lending/borrowing measures the extent to which the government is either placing resources for use by other sectors of the economy or utilizing their savings. It indicates the financial impact of the government on the rest of the economy.

The Statement of Other Economic Flows presents the influences on government Net Worth that are not the result of government transactions and asset consumption. Rather, they result from price changes in assets and liabilities (resulting in holding gains and losses) and from special events (natural disasters, new mineral discoveries and so on). These items are recorded directly in Net Worth and do not pass through the Statement of Government Operations.

The closing Balance Sheet presents the stock of assets and liabilities and shows the government's Net Worth. Change in Net Worth helps assess the sustainability of government operations. Declining net worth (consequent upon a running down of asset stocks or increasing liabilities as a result of net operating deficits) can indicate the non-sustainability of present fiscal policies. All the above statements are illustrated in the GFS Manual (2001:37, Figure 4.1)

In addition, a Cash Flow Statement is prepared and presented in the usual format of operating, investing and financing transactions. However, since 1999, the information in the statement is derived by adding back all non-cash items in the three main financial statements to determine the cash flows, rather than recording them directly from cash transactions as had occurred up to 1999. The unreliability of this method is obvious from the divergence in calculations based on each of the accrual accounting systems in Table 1. 
The GFS system based on accrual accounting is obviously a much superior information system to CABS because it reports on all assets, liabilities and operating costs, as well as on cash flows (when properly applied). It is a comprehensive FMIRS which is tailored to provide governments with appropriate information required for the good fiscal management of their economies. It can satisfy all the requirements for quality information specified in SAC3 of relevance, reliability with representational faithfulness, comparability and understandability. The information provided is relevant for the five major areas of fiscal policy management. All the reasons for the use of CABS for fiscal policy purposes apply equally to the GFS system. However in principle GFS is preferable because the recording of transactions as they occur matches the timing of the resource flows. But it should be noted that for the vast majority of government operating transactions, the time difference between the two is not significant, and that over 80 per cent of Commonwealth Government expenditures are cash transfers. By designing the GFS system to report simultaneously on cash and accrual transactions, the benefits of both systems can be obtained - GFS information for fiscal policy management and CABS for cash management and parliamentary cash appropriations. Furthermore, the information produced from the GFS system is closely linked to the other macroeconomic statistical systems including the national accounts, balance of payments and all the monetary and financial statistics produced by the government. All these important economic statistical systems are thereby integrated and mutually consistent.

Finally, it should be noted that the GFS system has been confined to date to the GGS for macroeconomic management purposes. It has not been applied at the departmental level for the management of resources and liabilities, and for operating cost management of departments and programs. This has been the preserve of the AAS AABS system. However, the GFS system can be readily extended and applied at the departmental level. In my opinion, it would provide better information for departmental management purposes and avoid many of the limitations of the AAS system as applied to government. It readily satisfies the SAC3 requirements for quality information. The GFS system applied at the micro level is essentially the Current Cost Accounting (CCA) system based on physical capital maintenance. This system is explained in Barton (1984:Chaps 24, 26) and in AASB (1983). Thus the GFS system could be used as a comprehensive FMIRS for the GGS for both macro and micro-economic management.

While the treatment of most transactions is very similar in the GFS and AAS systems, there are some significant differences with respect to the recognition and measurement of accounting events, asset and liability revaluations, expenditure on defence equipment, the treatment of the Goods and Services Tax, classification of items, concept of surplus, and the GGS as an accounting entity. These differences materially affect the financial statements. The differences are listed in Budget Paper No. 1, 2005-06 (8.10-13) and a reconciliation of the amounts for the two sets of budgets is provided. They are currently under review by HOTARAC and the AASB for the systems harmonisation project. 


\section{Australian Accounting Standards - Accrual Accounting and Budgeting System}

Australian Accounting Standards (AAS) were originally formulated by the AASB for business entities and subsequently applied, with some minor modifications, to the public sector. The standards developed specifically for the public sector (AAS29 and AAS31, 1996) adopt the same principles as the business standards and make allowances only for some different administrative arrangements in government. They are used throughout all government departments (as required by AAS29). Financial statements are prepared for each department and a consolidated set of financial statements is prepared for whole-of-government (as per AAS31) which includes financial and business enterprises. However, as indicated earlier, no outcome financial statements are prepared for the GGS. They are all subject to audit by the ANAO. AAS are heavily influenced by US and IASB standards because of the need to harmonise accounting standards in a world of global business. Moreover the IASB standards replaced the Australian standards 1 January 2005 under the Corporate Law Economic Reform Package.

The focus of AAS is on the preparation of information on accounting transactions and events to be included in General Purpose Financial Reports (GPFRs) for those stakeholders who have limited access to information about the entity. The objectives of GPFRs are stated as the provision of information useful to users for resource use decision making and evaluation, and for accountability purposes (SAC2, 1990:paras 43-45). The main financial reports produced are a statement of financial performance (formerly the profit and loss statement), a statement of financial position (formerly the balance sheet), and a cash flow statement. They are mainly similar in presentation to their GFS counterparts.

The AASB has adopted the principle that the same accounting standards should apply across all areas of economic activity, that is, be sector neutral (McGregor, 1999:3). Only minor variations in some procedures are allowed for specific industry characteristics. The public sector is treated as just another industry having some different characteristics to the norm, and the only major variation allowed is for departments to distinguish between 'administered items' (for example, transfer payments made according to legislation), and items controlled by departmental management. The Board does not accept that there are fundamental differences between the public and private sectors arising from the collective and/or social welfare roles of government versus the individual pursuit of profit by business firms.

Being designed for business activities, the focus of AAS is on the measurement of profit and financial position and on the reporting of this information in GPFRs to external investors and creditors. A balance sheet approach is used for the analysis of all transactions and events, in contrast to the resource flows and stocks approach used in the GFS system. The definition of assets forms the basis for all other definitions. Assets are defined as '... future economic benefits controlled by the entity as a result of past transactions or other 
events,' and control is defined as '... the capacity of the entity to benefit from the asset' (SAC4, 1990:para 14).

However, the standards are subject to some major limitations, even for the business sector. For example, there is no consistent financial measurement system in the standards because no basis of asset valuation is prescribed, and there are no concepts of profit (as distinct from a measurement rule) and capital maintenance prescribed. Assets and liabilities may be valued on a range of bases. This affects the measure of profit (through asset consumption charges and inclusion of some types of holding gains/losses directly in profit), and the stated financial position. Profit is defined to be the increase in net assets for the period (other than those arising from changes in direct owners' investment). Hence some unrealised holding gains (for example, an increase in the replacement cost of public roads and drains) may be treated as profit, even though the government is not 'better off' as the 'gains' are not realisable and the assets are not revenue generating.

But furthermore, some of the standards lack relevance for the public sector. For example:

- The role of accountability is more fundamental to government reporting than to business reporting (Mulgan, 2000). Democratic governments are accountable to citizens for all their activities. This requires that parliament and the public are kept fully informed of government policies and activities. Parliament can demand full access to specific information (subject to security and commercial in confidence considerations). Hence the distinction between general purpose financial reporting and management reporting in the public sector is not a sharp one. Government budgets and departmental reports are public documents unlike their business counterparts, which are for internal management use only.

- The definition of assets as future economic benefits where those benefits flow to the government as owner does not fit the bulk of non-financial government assets. Rather, they are acquired by governments to provide mainly non-cash services to citizens - health, education, defence, cultural services and so on.

- The definitions of the related concepts of revenue, expense, liabilities and equity, are not specifically appropriate for the public sector as they are based on an inappropriate definition of assets. For example, governments raise most of their revenue from taxation and not from user charges for goods and services provided to citizens, that is, sales transactions.

- Government departments are cost centres, not revenue generating profit centres concerned with the sale of goods and services. Departments are administrative arms of government whose function is to implement government policies in the provision of public goods and social welfare benefits, and they are primarily funded from budget appropriations (that is, taxes) to do so.

- Presentation of the operating statement as a Statement of Financial Performance is misleading. Financial results can be enhanced through raising taxes or curtailing services. This cannot be construed as being similar to 
businesses enhancing financial performance by increasing profits through raising sales revenue and by operating more efficiently. The statement as portrayed lacks representational faithfulness and is liable to be misunderstood.

- Presentation of the assets and liabilities of governments as Statements of Financial Position is likewise misleading. Most government non-financial assets are not revenue generating ones as are commercial assets. Moreover, at the departmental level, departments own no assets and have no liabilities; they are whole-of-government ones. Finally, if the negative net equity of whole-of-government were judged by business standards, the Government is bankrupt and should not be allowed to continue operating. However, governments do not need contributed capital as raised by companies to fund their fixed assets -- rather they have sovereign taxation powers and they only need to raise taxation revenue as and when required. Taxation powers are, rightly, not included in government balance sheets. The title of financial position is inappropriate and the statement would be better termed as one of assets and liabilities. It merely lists the assets and liabilities of the government without implying it provides a full measure of the financial position of the government.

These deficiencies of the AAS system for the public sector largely result from the failure to adapt the business accounting standards to the environment of government, the influence of business lobby groups pushing their own self-interest agendas on the standard setters (particularly in the US), and the ideological belief that business standards should be applied to the public sector so that the standards can be sector-neutral.

\section{Conclusions}

The present system of accounting in the Australian Government is untenable with the presentation of two sets of accrual budget statements and outcome financial statements which show very different results for all components; the absence of CABS which is needed for fiscal policy purposes, appropriation bills and good cash management, and the non recognition of the GGS as a financial reporting entity. In principle, the solutions are obvious ones - the reintroduction of CABS as a subset of AABS for the direct recording and timely reporting of cash transactions; harmonisation of the sound features of AAS and GFS into one combined, robust accrual accounting FMIRS system which is based on the GFS model and is relevant for the public sector; and the recognition of the GGS as a financial reporting entity.

The Government recognises the problem and consideration is currently being given to the reintroduction of CABS using the direct method as a component of AABS. The Heads of Treasury Committee is currently analysing the two AAB systems and making recommendations for changes in each in order to harmonise them wherever possible. Their recommendations are currently being considered 
by the AASB. Notwithstanding the many differences between the two systems, it should be acknowledged that there are also substantial overlaps between them and most of the accounting standards concerning transactions recognition and recording can be readily applied to the public sector; the differences primarily concern their reporting in the financial statements. The major deficiencies in AAS arising from their lack of sufficient conceptual and analytical rigour, consistency in the use of standards and the relevance of the standards to the public sector, can be overcome if there is the will to do so. Similarly there are some deficiencies in the GFS system which need to be remedied, such as the expensing of all expenditures on new military equipment. Making appropriate changes to each system would enable harmonisation of the systems and the use of one comprehensive accrual and cash FMIRS which provides relevant, reliable, comparable and understandable information on government activities for decision making, management control and accountability purposes. The prospective benefits from harmonisation are substantial.

\section{References}

Australian Accounting Standards Board (1996), Financial Reporting by Government Departments, AAS29, Melbourne.

Australian Accounting Standards Board (1996), Financial Reporting by Government ASCPA, AAS31, Melbourne.

Australian Accounting Standards Board (1983), Current Cost Accounting, SAP1, Melbourne.

Australian Accounting Standards Board (1990), Objective of General Purpose Financial Reporting, SAC2, Melbourne.

Australian Accounting Standards Board (1990), Qualitative Characteristics of Useful Information, SAC3, Melbourne.

Australian Accounting Standards Board (1990), Definition and Recognition of the Elements of Financial Statements, SAC4, Melbourne.

Australian National Audit Office (1996), 1995-96 Asset Management Audit Report No. 27, Canberra.

Barton, A. (1984), The Anatomy of Accounting, $3^{\text {rd }}$ ed, University of Queensland Press, Brisbane.

Barton, A. (2003), Accrual Accounting in Government: A Review of its Applications, Achievements and Problems and Proposals for Reform, CPA Australia, Melbourne.

Challen, D. and C. Jeffery (2003), 'Harmonisation of Government Finance Statistics and Generally Accepted Accounting Principles', Australian Accounting Review 13(2):48-53.

Challen, D. and C. Jeffery (2005), 'Definition of the Reporting Entity', Australian Accounting Review 15(1):71-78.

Commonwealth of Australia (2001), 2001-02 Budget Paper No 1, Canberra, May. 
Commonwealth of Australia (2004), Consolidated Financial Statements, 30 June, Canberra.

Commonwealth of Australia (2005), 2005-06 Budget Paper No. 1. Canberra, May.

Department of Finance (1994a), The New Financial Reports of Agencies, Commonwealth of Australia, Canberra, July.

Department of Finance (1994b), Resource Management in the Australian Public Sector, Commonwealth of Australia, Canberra, November.

Guthrie, J. and L. Parker (1998), 'Managerialism and Marketisation in Financial Management Change in Australia', pp. 49-75 in O. Olson, J. Guthrie and C. Humphrey (eds), Global Warning! Debating International Developments in New Public Management, Cappelen Akademisk, Forag, Bergen, Norway.

International Monetary Fund (2001), Government Finance Statistics Manual, Washington.

Joint Committee of Public Accounts and Audit (1995a), Accrual Accounting, A Cultural Change, Report 338, AGPS, Canberra.

Joint Committee of Public Accounts and Audit (1995b), Financial Reporting for the Commonwealth: Towards Greater Transparency and Accountability, Report 341, AGPS, Canberra.

Joint Committee of Public Accounts and Audit (2002), Review of Accrual Budget Documentation, Report No. 388, Canberra.

McGregor, W. (1999), 'The Pivotal Role of Accounting Concepts in the Development of Public Sector Accounting Standards', Australian Accounting Review 9(1):3-8.

Micallef, F., P. Sutcliffe and P. Doughty (1994), Financial Reporting by Governments, AARF, Discussion Paper 21, Melbourne.

Mulgan, R. (2000), 'Comparing Accountability in the Public and Private Sectors', Australian Journal of Public Administration 59(1):87-97.

National Commission of Audit, (1996), Report to the Commonwealth Government, AGPS, Canberra.

Stiglitz, J. (1999), Economics of the Public Sector, $3^{\text {rd }}$ ed, Norton, New York.

Sutcliffe, P., F. Micallef, and L. Parker (1991), Financial Reporting by Government Departments, Discussion Paper 16, AARF, Melbourne.

Wanna, J., J. Kelly, and J. Forster (2000), Managing Public Expenditure in Australia, Allen \& Unwin, Sydney.

I wish to thank Professor Graeme Wells for his suggestions for the preparation of this article. 